\title{
BURNOUT AND ENGAGEMENT: A SOUTH AFRICAN PERSPECTIVE
}

\author{
S. ROTHMANN \\ WorkWell: Research Unit for People, Policy and Performance, \\ Faculty of Economic \& Management Sciences \\ PU for CHE
}

\begin{abstract}
Work wellness, and more specifically burnout and engagement are important focus areas of research and intervention in South Africa. However, few studies have been conducted regarding the factorial validity, construct equivalence and item bias of measuring instruments of burnout and work engagement. Furthermore, few studies have been conducted regarding causal models of burnout as well as interventions to prevent and/or manage burnout in a multicultural context. Little is known about the causes of work engagement and interventions to increase it. Research should be conducted to validate measuring instruments of burnout, work engagement and predictors thereof in multicultural contexts. Research is also needed regarding the effectiveness of interventions to manage work engagement and to prevent and/or manage burnout.
\end{abstract}

\section{OPSOMMING}

Werkwelstand, en meer spesifiek psigiese uitbranding en begeestering is belangrike fokusareas vir navorsing en intervensie in Suid-Afrika. Tog is min studies onderneem rakende die faktorgeldigheid, konstrukekwivalensie en itemsydigheid van meetinstrumente van psigiese uitbranding en werksbegeestering. Verder is min studies onderneem ten opsigte van oorsaaklike modelle van psigiese uitbranding sowel as intervensies om uitbranding in ' $n$ multikulturele konteks te voorkom en/of te bestuur. Min is bekend oor die oorsake van werksbegeestering en intervensies om dit te verhoog. Navorsing moet onderneem word ten einde meetinstrumente van psigiese uitbranding, werksbegeestering en voorspellers daarvan in ' $n$ multikulturele konteks te valideer. Navorsing rakende die effektiwiteit van intervensies om werksbegeestering te bestuur en psigiese uitbranding te voorkom en/of te hanteer, is ook noodsaaklik.

Work often generates ambivalent feelings. On the one hand work requires effort and is associated with lack of freedom and negative feelings. On the other hand work gives energy, enables development and generates positive feelings. Accordingly, it seems that work could lead to illness as well as health (Schaufeli \& Bakker, 2001; Turner, Barling \& Zacharatos, 2002).

One perspective is that work could cause illness. Research in the Netherlands showed that between $4 \%$ and $10 \%$ of the working population reported serious burnout complaints (Bakker, Schaufeli \& Van Dierendonck, 2000). Studies in South Africa confirm the negative effects of work. For example, Pienaar (2002) found that $8,64 \%$ of a sample of 2396 police officers showed serious levels of suicide ideation, while $15 \%$ reported stressrelated problems. Levert, Lucas and Ortlepp (2000) reported that $54,9 \%$ of psychiatric nurses in their study in government hospitals experienced a high level of emotional exhaustion, while Van der Linde, Van der Westhuizen and Wissing (1999) found that $29 \%$ of female teachers in their study showed high levels of emotional exhaustion. Therefore the conclusion that work may result in illness seems to be legitimate.

However, in contrast with the above-mentioned argument it seems that work, and more specifically goal-directed, structured activity, translate directly into other mental health outcomes (Kelloway \& Barling, 1991) and indirectly affect employees' life satisfaction (Hart, 1999; Judge \& Watanabe, 1993). In helping, work is used to promote psychological well-being, for example occupational therapy for psychiatric patients. In addition, studies (e.g. Kirchler, 1985; Warr, 1983) regarding the effects of unemployment showed that a lack of work has detrimental effects, such as depression, alcoholism, psychological complaints and even suicide. Therefore it can be concluded that work could either contribute to illness or could have a therapeutic effect.

Traditionally the health and social sciences have been characterised by a pathogenic paradigm, i.e. an orientation

Requests for copies should be addressed to: S Rothman, WorkWell: Research Unit for People, Policy and Performance, Faculty of Economic \& Management Sciences, PU for CHE, Private Bag X6001, Potchefstroom, 2520 towards the abnormal, with the fundamental question being: "Why do people fall ill?" (Strümpfer, 1990). Knowledge gained by answering this question is then used to find ways of treating and preventing diseases. Diener, Suh, Lucas and Smith (1999) showed that 17 times more scientific articles were published on negative feelings than on positive feelings. Myers (2000) found a more favourable ratio of 14:1. He mentions that since 1887, 8000 articles have been published in Psychological Abstracts about anger, almost 57000 about anxiety and almost 70000 about depression. In comparison, 851 of the published articles were about joy, 2958 about happiness and 5701 about satisfaction. The focus of psychology has been on detecting deficits, which Schaufeli and Bakker (2001) labelled "psychologie als een wetenschap van het gebrek". Since 1996 only $6 \%$ of the articles published in the Journal of Occupational Health Psychology focused on positive aspects of health and well-being. The other $94 \%$ were related to burnout, post-traumatic stress disorder, stress, conflict and psychosomatic complaints.

In contrast to the pathological interest in "what can go wrong", there have been attempts to discover "what can go right" (Strümpfer, 2002). It is a radically different set of assumptions and attributions about health and potential. During 2000, a whole edition of the American Psychologist focused on what was called "positive psychology" (Ryan \& Deci, 2000; Seligman \& Csikszentmihalyi, 2000). Seligman and Csikszentmihalyi (2000, p. 5) wrote: "The field of positive psychology at the subjective level is about valued subjective experiences; well-being, contentment, and satisfaction (in the past); hope and optimism (for the future) and flow and happiness (in the present)". Up to then, various international authors have proposed concepts referring to positive psychology.

The humanistic psychology which manifested as a "third force" in psychology (next to the psychoanalysis and behaviourism) in the 1950s could be regarded as a precursor of positive psychology. Antonovsky (1979) introduced the concept of salutogenesis $($ Latin salus $=$ health, Greek genesis $=$ origin), proposing that the origins of health rather than disease should be studied. Strümpfer (1995) argued that the concept of salutogenesis should be broadened from a focus on 
health only, to fortigenesis (Latin fortis = strong) referring to strength. Wissing and Van Eeden (1997) suggested a new subdiscipline of psychofortology and suggested that not only the origins of psychological well-being should be studied, but also the nature, manifestations and ways to enhance psychological well-being.

Also in industrial and organisational psychology there is a tendency to focus mainly on negative implications in research and practice. Burnout, stress, violations of psychological contracts, job insecurity and downsizing remain the most popular topics for study (Turner et al., 2002). Therefore, it is no surprise to find not a single chapter of the Handbook of Work and Health Psychology (Schabracq, Winnubst \& Cooper, 1996) focussing on health and well-being at work. However, the recently published Handbook of Positive Psychology (Snyder \& Lopez, 2002) contains one chapter referring to positive psychology at work. Furthermore, Schaufeli and Bakker (2001) point out that industrial and organisational psychology (in contrast with other fields in psychology) focuses more on positive concepts such as job satisfaction, organisational commitment, organisational citizenship behaviour and intrinsic motivation.

Adopting a utilitarian, cost-benefit perspective emphasizing the goal of enhanced workplace performance, Luthans (2002a, $2002 \mathrm{~b}$ ) noted the need for a more relevant, proactive approach to organisational research, which he termed positive organisational behaviour. Adopting what Keyes and Haidt (2003) refer to as a 'repair shop' perspective, applied research has tended to focus unduly on identification of financial costs to the organisation of distressed, dissatisfied and unhappy employees. The cause of this employee dissatisfaction and unhappiness is typically seen from this 'repair shop' perspective as being deeply imbedded in the emotional maladjustment of the employee, as opposed to aspects of the job itself (Wright, 2003). As a result, the cure for this maladjustment usually involves some type of prevention-based employee therapy (Wright \& Cropanzano, 2000), while more promising positive organisational behaviour approaches to organisational research are emerging (Wright, 2003).

The environment in which employees in South Africa and elsewhere in the world currently function demands more of them than did any previous period. The employment relationship has changed, altering the type of work that people do, when they work and how much they do (Barling, 1999). Some employees also face diminished choice and control in that they are forced to take on hours and working arrangements that are against their preferences (Turner et al., 2002). Additional unpredictability results as many employers move toward greater flexibility by expanding and shrinking the work force to correspond with shifting production and service demands, resulting in a loss of control over working hours but also a sense of job insecurity (Martin, 1997). Many organisations have implement practices that attempt to reduce costs and increase productivity, which often leads to a mentality that favours profitability over the welfare of people (Turner et al., 2002).

In sum, employees have to cope with many demands often with limited resources, and a lack of control. Tracking and addressing their effectiveness in coping with new demands and stimulating their growth in areas that could possibly impact on individual well-being and organisational efficiency and effectiveness are therefore crucial. From a pathogenic as well as a fortigenic perspective burnout and work engagement are specific focus areas for research and intervention (Maslach, Schaufeli \& Leiter, 2001). Burnout is a metaphor that is commonly used to describe a state or process of mental exhaustion (Schaufeli \& Enzmann, 1998). Engagement is defined as an energetic state in which the employee is dedicated to excellent performance at work and is confident of his or her effectiveness (Schutte, Toppinen, Kalimo \& Schaufeli, 2000).
Schaufeli and Bakker (2001) developed a model of well-being at work which makes it possible to focus on burnout and engagement. The model is illustrated in Figure 1.

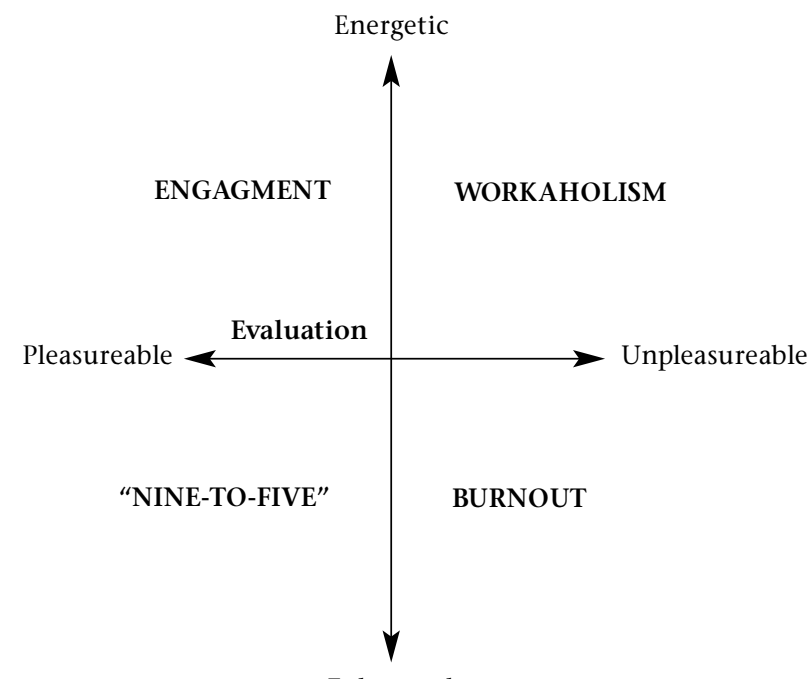

Exhausted

Figure 1: A taxonomy of well-being at work

Schaufeli and Bakker (2001) distinguish between two dimensions that could be used to classify four types of wellbeing at work. The horizontal axis represents the extent of pleasure at work (i.e. pleasurable versus unpleasurable). The vertical dimension relates to the mobilisation of energy. This taxonomy makes it possible to distinguish between engagement and burnout, but also workaholism and a type of work experience called "nine-to-five".

According to Schaufeli and Bakker (2001), research on burnout showed that some employees, regardless of high job demands and long working hours, were not burned out. Instead, it seemed that they found pleasure in working hard and dealing with job demands. They may be seen as workaholics, that is, if the perspective is one of focussing on human deficiencies (rather than on strengths). Therefore, the question arises whether it is not possible that there are engaged employees who show energy, dedication and absorption in their work, i.e. employees who show behaviour that is the opposite of burnout.

While a positive fortigenic perspective would probably require that concepts such as engagement and psychological strengths that could prevent burnout should be studied, harsh realities exist that contribute to stress and burnout. Rothmann and Van Rensburg (2002) argued that stress in the SAPS contributes to the decline in psychological strengths. Psychological strengths are probably insufficient to resist the detrimental effects of a harsh environment (e.g. a constantly demanding work situation). The latter argument is supported by studies which showed that dispositional factors explain not more than $30 \%$ of the variance in work-related outcomes (e.g. job satisfaction and burnout) (Rothmann, 2001; Kruger, Veldman, Rothmann \& Jackson, 2002). Cherniss (1995, p. 166) also warns against overemphasising personal virtues: "Recognizing that certain individual characteristics help professionals avoid burnout shouldn't distract us from the powerful factors in the work environment that lead to burnout."

The objective of this study is to summarise research regarding burnout and engagement, as well as possible psychological strengths that could prevent burnout or facilitate engagement to determine important research themes regarding these aspects.

\section{Burnout}

Herbert Freudenberger (1974) introduced the term "burnout" in the mid-1970s. He used it to describe the symptoms of emotional 
depletion and a loss of motivation and commitment amongst volunteers with whom he was working in an alternative care setting (Freudenberger, 1974). Burnout first emerged as a social problem, not as a scholarly construct. Therefore, during the pioneering phase, the initial conception of burnout was shaped by pragmatic rather than academic concerns, the work was exploratory and the goal to articulate the burnout phenomenon (Maslach \& Schaufeli, 1993; Maslach et al., 2001). In the second empirical phase, burnout research became more systematic and quantitative in nature. Larger study samples were used and the focus shifted to the assessment of burnout, utilising questionnaire and survey methodology (Maslach et al., 2001). Furthermore, the concept of burnout that was initially closely linked to the human services where people do 'people' work of some kind has been expanded to all other professions and occupational groups.

Probably the most frequently cited definition of burnout comes from Maslach and Jackson, (1986, p. 1). They defined burnout as a syndrome of emotional exhaustion, depersonalisation and reduced personal accomplishment that can occur among individuals who do "people work" of some kind. Schaufeli and Enzmann (1998, p. 36) also identified exhaustion as a core indicator of burnout and a sense of reduced effectiveness as an accompanying symptom, but added three additional general symptoms, namely distress (affective, cognitive, physical and behavioural), decreased motivation, and dysfunctional attitudes and behaviours at work. They define burnout as "a persistent, negative, work-related state of mind in 'normal' individuals that is primarily characterised by exhaustion, which is accompanied by distress, a sense of reduced effectiveness, decreased motivation, and the development of dysfunctional attitudes and behaviours at work"

Although Maslach and Jackson (1986, p. 1) defined burnout as "... a syndrome of emotional exhaustion and cynicism that occurs among individuals who do people work of some kind", researchers currently acknowledge that employees in almost any job can develop burnout (Schaufeli \& Enzmann, 1998). In the third edition of the manual of the Maslach Burnout Inventory (Maslach, Jackson \& Leiter, 1996), the concept of burnout is defined as a crisis in one's relationship with work in general and not necessarily as a crisis in one's relationship with people at work.

Exhaustion is a necessary but not sufficient criterion for burnout (Maslach, 1998). The notion of exhaustion presupposes a prior state of high arousal or overload rather than one of low arousal or underload, which implies that burnout is not a response to tedious, boring or monotonous work. However, exhaustion fails to capture a critical aspect of the relationship people have with their work. Chronic exhaustion can lead people to distance themselves emotionally and cognitively from their work, so that they are less involved with, or responsive to the needs of other people or the demands of the task. According to Maslach (1998), distancing is such an immediate reaction to exhaustion that a strong relationship from exhaustion to depersonalisation or cynicism is consistently found in burnout research. Furthermore, a work situation with chronic, overwhelming demands that contribute to exhaustion or cynicism is likely to erode an individual's sense of accomplishment or effectiveness. Also, it is difficult to gain a sense of accomplishment when feeling exhausted or when helping people toward whom one is hostile. In some situations the lack of efficacy seems to arise more clearly from a lack of relevant resources, while exhaustion and cynicism appears from the presence of work overload and social conflict (Maslach, 1998).

The dimensions of burnout are conceptualised differently, depending on the nature of the job concerned. In the helping professions (including education), three dimensions of burnout are distinguished, namely emotional exhaustion, depersonalisation and low personal accomplishment. In jobs other than the helping professions the dimensions of burnout are labelled as exhaustion, cynicism and low personal efficacy (Maslach et al., 1996).

The consequences of burnout are potentially serious for staff, clients and the larger institutions in which they interact. Maslach and Jackson (1986) suggested that burnout could lead to deterioration in the quality of care or service that is provided by the staff. It correlates with various self-reported indices of personal dysfunction, increased use of alcohol and drugs, and marital and family problems (Maslach \& Jackson, 1986). Managers suffering from burnout could hurt the organisation because they spread it to their subordinates (DuBrin, 1990). Burnout is a self-perpetuating process that affects the attainment of professional goals and depletes the resources of the individual to cope with the process and symptoms of burnout. Furthermore, it appears to be a factor in job turnover, absenteeism, low morale and job dissatisfaction.

\section{Work engagement}

Research on the engagement concept has taken two different but related paths. Maslach and Leiter (1997, p. 23) rephrased burnout as "an erosion of engagement with the job". Work that started out as important, meaningful and challenging becomes unpleasant, unfulfilling and meaningless. In the view of these authors, engagement is characterised by energy, involvement and efficacy, which are considered the direct opposites of the three burnout dimensions, namely exhaustion, cynicism and lack of professional efficacy respectively. Therefore, they also assess engagement by the opposite pattern of scores on the three Maslach Burnout Inventory (MBI) dimensions - low scores on exhaustion and cynicism, and high scores on efficacy are indicative for engagement.

Schaufeli and his colleagues partly agree with Maslach and Leiter's (1997) description, but take a different perspective and define and operationalise engagement in its own right. Schaufeli, Salanova, González-Romá and Bakker (2002) consider burnout and engagement to be opposite concepts that should be measured independently with different instruments. Furthermore, burnout and engagement may be considered two prototypes of employee well-being that are part of a more comprehensive taxonomy constituted by the two independent dimensions of pleasure and activation (Watson \& Tellegen, 1985). Activation ranges from exhaustion to vigour, while identification ranges from cynicism to dedication. According to this framework, burnout is characterised by a combination of exhaustion (low activation) and cynicism (low identification), whereas engagement is characterised by vigour (high activation) and dedication (high identification).

Maslach and Leiter (1997) suggest that the three dimensions of burnout have a bipolar character and that burnout and engagement will show strong negative correlations. However, it is noted that a positive concept is measured by negative items (i.e. regarding exhaustion and cynicism). Although Schaufeli and Bakker (2001) also regard burnout and engagement as opposites, they believe that the two concepts should be measured independently. This makes it possible to investigate the relationship between burnout and engagement empirically. Schaufeli and Bakker (2002) state that "feeling emotionally drained from one's work 'once a week' does by no means exclude that in the same week one might feel bursting with energy."

According to Schaufeli and Bakker (2001), two dimensions of engagement are logically related to burnout, namely vigour (exhaustion) and dedication (cynicism). Vigour refers to the activation dimension of well-being, while dedication refers to identification with work. However, absorption and professional efficacy seem to be less related than the other dimensions, but 
both dimensions might also be regarded as components of engagement. Schaufeli and Bakker (2002) found that burnout and engagement are negatively related, sharing between $10 \%$ and $25 \%$ of their variance. Storm (2002) found a canonical correlation of 0,51 between burnout and engagement. A moderately negative correlation $(r=-0,42)$ was found between cynicism and dedication. Vigour correlated negatively with exhaustion $(r=-0,28)$.

Schaufeli and Bakker (2001) define engagement as a positive, fulfilling, work-related state of mind that is characterised by vigour, dedication, and absorption. Rather than a momentary and specific state, engagement refers to a more persistent and pervasive affective-cognitive state that is not focused on any particular object, event, individual or behaviour. Engagement consists of the following dimensions (Schaufeli \& Bakker, 2001):

- Vigour is characterised by high levels of energy and mental resilience while working, the willingness to invest effort in one's work, not being easily fatigued, and persistence even in the face of difficulties.

- Dedication is characterised by deriving a sense of significance from one's work, by feeling enthusiastic and proud about one's job, and by feeling inspired and challenged by it.

- Absorption is characterised by being totally and happily immersed in one's work and having difficulties detaching oneself from it. Time passes quickly and one forgets everything else that is around.

\section{Measurement of burnout and work engagement}

The importance of reliable and valid instruments for the measurement of burnout and work engagement is evident not only for the purpose of empirical research, but also ultimately for individual assessment. When determining factorial validity, confirmatory factor analysis (through structural equation modelling) should be used, because exploratory factor analysis shows some weaknesses (Byrne, 1991). Also, when burnout and work engagement measures are applied to different cultural groups, issues of measurement bias and equivalence become important (Van de Vijver \& Tanzer, 1997). According to Van de Vijver and Leung (1997), equivalence and bias of measuring instruments should be reported in each study that takes place in a multicultural context. Construct equivalence (also labelled structural equivalence) is the most frequently studied type of equivalence (Van de Vijver \& Leung, 1997). It indicates the extent to which the same construct is measured across all cultural groups. Furthermore, item bias should be computed. An item is an unbiased measure of a theoretical construct, for example burnout, if persons from different cultural groups who are equally burned out have the same average score on the item (Van de Vijver \& Leung, 1997).

The Maslach Burnout Indicator (MBI) is the most accepted instrument for measuring burnout (Schaufeli \& Enzmann, 1998). Three versions of the MBI were developed, namely the MBI-HSS (Human Services Survey), MBI-ED (Educators) and MBI-GS (General Survey) (Maslach, Jackson \& Leiter, 1997). The first and second versions measure three dimensions, namely Emotional Exhaustion, Depersonalisation and Personal Accomplishment, while the third version measures Exhaustion, Cynicism and Professional Efficacy. Recently, Schaufeli, Martinez, Pinto, Salanova and Bakker (2002) developed a student version of the MBI.

The basic three-factor structure underlying the MBI-HSS has been repeatedly confirmed by exploratory and confirmatory factor analyses in Western countries (Boles, Dean, Ricks, Short \& Wang, 2000; Gorter, Albrecht, Hoogstraten \& Eijkman, 1999; Schaufeli, Bakker, Hoogduin, Schaap \& Kladler, 2001). Also, South African studies were found where the factorial validity and internal consistency were not reported (e.g. Ross \& Fridjhon, 1995). Naudé and Rothmann (in press) found support for the factorial validity of a 17 -item version of the MBI-HSS in a sample of emergency workers in South Africa. They found that the construct equivalence of the MBI-HSS was not acceptable for the Nguni language group (compared with Afrikaans, English and Sotho groups). Also three items of the original inventory had to be removed because they showed either uniform or nonuniform bias, which was attributed to difficulty to understand the meaning of English words. The MBI-HSS (Maslach \& Jackson, 1986) has evidenced relatively high internal consistency in Europe (Kalliath, O'Driscoll, Gillespie \& Bluedorn, 2000; Schaufeli \& Van Dierendonck, 1995) and South Africa (Basson \& Rothmann, 2002; Levert et al., 2000; Naude \& Rothmann, in press) with alpha coefficients varying between 0,67 (Depersonalisation) and 0,89 (Emotional Exhaustion). However, in many South African studies the factorial validity, construct equivalence and item bias of the MBI-HSS were not investigated.

Byrne (1991) studied the factorial validity of the MBI-ED for teachers at intermediate, secondary and university levels in Canada and found support for a 3-factor model after the deletion of four scale items. Acceptable internal consistencies of the three scales, ranging from 0,76 to 0,90 were found for the MBI-ED. Pretorius (1994) found that a good fit exist for the 3-factor model of the MBI for educators in South Africa. Internal consistencies of the three scales varied from 0,71 (Depersonalisation) to 0,89 (Emotional Exhaustion). However, it is not clear which version of the MBI was used. Furthermore, the sample consisted only of 94 faculty members at one university, which make generalisation of results problematic. Van der Linde et al. (1999) reported internal consistencies of 0,89 (Emotional Exhaustion), 0,67 (Depersonalisation) and 0,70 (Personal Accomplishment) of the MBI-ED in a sample of female teachers in South Africa. Although a relative large sample $(\mathrm{N}=421)$ of female educators was studied they did not report any results regarding the factorial validity of the MBI-ED.

Regarding the MBI-GS, internal consistencies are equally satisfactory, ranging from 0,73 (Cynicism) to 0,91 (Exhaustion) (Leiter \& Schaufeli, 1996). Reliability analyses done by Schutte et al. (2000) showed that the Exhaustion and Professional Efficacy sub-scales were sufficiently internally consistent, but that one Cynicism item should be removed in order to increase the internal consistency beyond the criterion of 0,70 . According to them, this might be caused by the ambivalence of the particular item: "I just want to do my job and not be bothered". In their studies, Schaufeli, Leiter and Kalimo (1995) and Leiter and Schaufeli (1996) also found that this item had the lowest factor loadings of the three sub-scales.

Four studies that used the MBI-GS in South African samples were found. In a sample of senior managers in a manufacturing industry, Rothmann and Jansen van Vuuren (2002) found satisfactory alpha coefficients: Exhaustion $=0,79$; Cynicism $=$ 0,84 (after item 13 had been omitted); Professional Efficacy = 0,84 . Rothmann and Malan (2002) found higher alphas (Exhaustion $=0,89$; Cynicism $=0,76$; Professional Efficacy $=$ $0,85)$, while Kruger et al. (2002) found lower alphas for Cynicism $(0,72$ after item 13 had been omitted) and Professional Efficacy $(0,69)$. Storm and Rothmann (2003b) found alpha coefficients of 0,88 (Exhaustion), 0,78 (Cynicism) and 0,79 (Professional Efficacy) in a sample of 2396 police officers in South Africa.

A large body of research has addressed the factor structure of the MBI-HSS (Maslach \& Jackson, 1986), but it seems as if there is a paucity of research on the internal and external validity of the MBI-GS (Taris, Schreurs \& Schaufeli, 1999). Confirmatory factor analysis done by Schutte et al. (2000) showed that the threefactor model was clearly superior to alternative one-factor and two-factor models. Schaufeli et al. (2002) confirmed these findings. Leiter and Schaufeli (1996) employed confirmatory factor analysis using linear structural equation modelling and also confirmed a three-factor structure. Similar results were obtained by Taris et al. (1999). 
Confirmatory factor analyses by Rothmann and Jansen van Vuuren (2002), Rothmann and Malan (2002) and Kruger et al. (2002) consistently showed low loadings on item 13 of the MBIGS on Cynicism. Storm and Rothmann (2003b) used structural equation modelling (SEM) methods as implemented by AMOS (Arbuckle, 1997) to test the factorial model for the MBI-GS on a random, stratified sample in the South African Police Services $(N=2396)$. Prior to testing the 3 -factor model of burnout, a 1 factor model was tested. However, the 1-factor model showed poor fit, while a 3 -factor model, using 15 of the original items resulted in a good fit.

Storm and Rothmann (2003b) conducted an exploratory factor analysis and used target (Procrustean) rotation to determine construct equivalence of the MBI-GS for race groups. They found acceptable Tucker's coefficients of agreement (Tucker's phi) higher than 0,95 for all the groups, which shows construct equivalence of the MBI-GS. They did not found evidence for uniform or non-uniform bias of the items of the MBI-GS for different race groups.

More research is also needed regarding the phrasing of MBI items as well as the conceptualisation of the dimensions. Recent research showed that the psychometric value of the MBI-GS could be greatly enhanced by including positively phrased items of the Disengagement Scale of the Oldenburg Burnout Inventory (OLBI) (Demerouti, Bakker, Vardakou \& Kantas, 2003). Disengagement, described as distancing oneself from work and experiencing negative attitudes towards work, its content and work in general, was found to be significantly related to Cynicism (the opposite of Depersonalisation in the MBI-HSS). Positive items on the Depersonalisation scale of the MBI-HSS should be developed and tested in future studies to determine whether this scale is an artefact of the MBI-HSS due to its one-sidedness. In the general sense, the measurement of burnout could be improved psychometrically by including positively phrased items which could even lead to the expansion of the burnout construct beyond Cynicism to a factor measuring mental disengagement from the work object, work content and work in general. Also, negative worded items should be included to measure Professional Efficacy (Bouman, Te Brake \& Hoogstraten, 2002).

A major problem with the MBI is the lack of clinically validated cut-off points (Schaufeli et al., 2001). Future research should therefore focus on the development of clinical guidelines in terms of burnout to enable comparison and identification according to national guidelines. Schaufeli and Van Dierendonck (1995) and Schaufeli et al. (1995) found that levels of burnout differed among national samples, therefore comparisons with norms in other countries are impossible. Because burnout is not included in the DSM IV classification, individuals who suffer from neurasthenia could be used to determine the cut-off points.

Regarding the measurement of engagement, Schaufeli et al. (2002) disagree with Maslach and Leiter (1997), who stated that engagement is adequately measured by the opposite profile of MBI scores. Schaufeli et al. (2002) argue that, by using the MBI for measuring engagement, it is impossible to study its relationship with burnout empirically since both concepts are considered to be opposite poles on a continuum that is covered by one single instrument (the MBI). Although they agree that engagement is the positive antithesis of burnout, they acknowledge that the measurement and the structures of both concepts differ.

Schaufeli et al. (2002) developed the Utrecht Work Engagement Scale (UWES) and found acceptable reliability for it. Two recent studies using confirmative factor analysis demonstrated the factorial validity of the UWES (Schaufeli et al., 2001; Schaufeli et al., 2002). The three scales are moderately to strongly related (mean $r=0,63$ in Sample 1 and mean $r=0,70$ in Sample 2). Also, the fit of the hypothesised three-factor model to the data was superior to a one-factor solution (Maslach et al., 2001; Schaufeli et al., 2002).

Rothmann and Storm (2003) and Naudé (2003) studied the internal consistency, factorial validity, structural equivalence and bias of the UWES in South Africa. Although structural equation modelling supported a three-factor model of work engagement in both studies, the correlations between the three dimensions (i.e. vigour, dedication and absorption) were high, suggesting the possibility that work engagement (as measured by the UWES) is a one dimensional construct. Cronbach alpha coefficients of the scales were acceptable compared to the guideline of $\alpha>0,70$ (Nunnally \& Bernstein, 1994). While Rothmann and Storm (2003) confirmed the structural equivalence of the UWES for four race groups, Naudé (2003) found that the UWES did not show structural equivalence for the Nguni language group. Based on these results it was recommended that the items of the MBI and UWES be mixed to prevent response patterns, the wording of the items of the UWES be simplified and that the UWES be translated to the languages that are used in South Africa.

\section{Causes of burnout and engagement}

Various theories could be used to understand and predict stress, burnout and work engagement in South Africa.

Burnout implies a rather long temporal process since it is based on the fact that the person has been working for a while and is experiencing a chronic misfit between self and work. Recently Maslach and Leiter (1997) have formulated a model that focuses on the degree of match or mismatch between the person and six domains of his or her job environment, namely workload, control, rewards, community, fairness and values (Maslach, 1998).

- Work overload occurs when job demands exceed human limits, i.e. when individuals have to do too much in too little time with too few resources.

- Lack of control occurs when individuals have little control over the work they do, either because of rigid policies and tight monitoring, or because of chaotic job conditions.

- Insufficient reward involves a lack of appropriate rewards for the work people do. Both external rewards (e.g. salary and benefits) and internal rewards (pride in doing something of importance) could result in a mismatch.

- Breakdown of community occurs when people loss a sense of positive connection with others in the workplace. Chronic and unresolved conflicts with others on the job also result in breakdown of community.

- Absence of fairness occurs when there is a lack of a system of fair procedures which maintain mutual respect in the workplace. Unfairness can occur when there is inequity of workload or pay, or when evaluations and promotions are handled inappropriately.

- Value conflict occurs when there is a mismatch between the requirements of a job and people's principles.

The greater the gap, or mismatch, between the person and the job, the greater the likelihood of burnout, conversely, the greater the match, the greater the likelihood of engagement with work. Research is needed to test the fit of the model of Maslach and Leiter (1997) in the South African context. Also, this model does not differentiate between factors which contribute to burnout and work engagement, because the two concepts are regarded as opposites by Maslach (1998). Storm and Rothmann (2003) and Naudé and Rothmann (2003) found that different sets of causal factors play a role in burnout and work engagement respectively.

Demerouti, Bakker, Nachreiner and Schaufeli (2001b) developed the Job Demand-Resources (JD-R) model and confirmed that job demands (e.g. physical demands, time pressure and shift work) are associated with exhaustion, whereas lacking job resources (e.g. feedback, participation in decision making and supervisory 
support) are associated with disengagement. The JD-R model assumes two processes, namely an energetic process of wearing out in which high job demands exhaust the employee's energy, as well as a motivational process in which lacking resources preclude dealing effectively with job demands and foster mental withdrawal. Studies in South Africa (e.g. Levert et al., 2000; Pretorius, 1994; Storm \& Rothmann, 2003) confirmed that burnout is related to job demands. In a sample of educators in South Africa, Pretorius (1994) found that role conflict and number of students explained $25 \%$ of the variance in emotional exhaustion. Number of students and role ambiguity explained $15 \%$ of the variance in depersonalisation, while participation in decision-making explained $8 \%$ of the variance in personal accomplishment. Levert et al. (2000) reported that emotional exhaustion and depersonalisation of psychiatric nurses were predicted by work load, lack of collegial support, role conflict and role ambiguity.

Schaufeli and Bakker (2002) extended the JD-R model by including engagement and by adding indicators for health impairment and organisational withdrawal in the Comprehensive Burnout and Engagement (COBE) Model. The COBE-model assumes two psychological processes, namely an energetic and a motivational process. The energetic process links job demands with health problems via burnout. The motivational process links job resources via engagement with organizational outcomes. Job resources may play either an intrinsic motivational role (by fostering the employee's growth, learning and development), or they may play an extrinsic motivational role (by being instrumental in achieving work goals). Schaufeli and Bakker (2002) confirmed the model in an empirical study in the Netherlands. Job demands were associated with exhaustion, whereas job resources were associated with engagement. Burnout was related to health problems as well as to turnover intentions, and mediated the relationship between job demands and health problems, while engagement mediated the relationship between job resources and turnover intentions.

Personality traits could affect employees' burnout. In most studies it was found that neuroticism was positively related to exhaustion (Schaufeli \& Enzmann, 1998). Exhaustion also correlates significantly with extraversion, agreeableness and conscientiousness. Depersonalisation is negatively related to agreeableness. Reduced personal accomplishment is related to extraversion. In a South African study, Storm and Rothmann (2002) found that Emotional Stability, Extraversion, Openness to Experience, Agreeableness and Conscientiousness were associated with lower emotional exhaustion and depersonalisation and higher personal accomplishment.

Based on the work of Ryan and Deci (2000), it could be argued that social-contextual events (e.g., feedback, communications and rewards) will affect engagement. Ryan and Deci found that optimal challenges, feedback and freedom from demeaning evaluations facilitate intrinsic motivation (which seems to be related to engagement). Positive performance feedback enhances engagement, whereas negative performance feedback diminishes it, although it seems that these effects are mediated by perceived competence. Furthermore, feelings of competence will not enhance engagement unless accompanied by a sense of autonomy or, in attributional terms, by an internal perceived locus of control. Therefore, people must not only experience competence or efficacy, they must also experience their behaviour as self-determined for engagement to be in evidence. This requires either immediate contextual supports for autonomy and competence or abiding inner resources that are typically the result of prior developmental supports for perceived autonomy and competence.

According to Roberts and Davenport (2002), there are three areas that could be targeted to increase employees' work engagement, namely career development, identification with the organisation and a rewarding work environment. Career development includes providing opportunities for employees to learn new skills and to develop themselves, as well as opportunities to advance in the organisation and helping them to manage their careers. Identification with the organisation is enhanced when employees know that they will share in the success if the organisation is financially successful, they consider their departments' goals to be their own, they are satisfied with their involvement in decisions that affect their work, and they are proud of the quality of work they do. A rewarding work environment is characterised by a positive, fun working environment, employees having the decision-making authority to do their jobs well, recognition for contributions, encouragement to look for new and better ways of doing things, and supervisors who create a motivating climate.

From a fortigenic paradigm (Strümpfer, 1995), psychological strengths create tendencies contrary to those that produce burnout or are favourable to work engagement. These strengths include amongst others a sense of coherence (Antonovsky, 1987), self-efficacy (Bandura, 1977), an internal locus of control (Rotter, 1966), optimism (Carver \& Scheier, 2002) and life satisfaction (Diener, Lucas \& Oishi, 2002).

- Sense of coherence. Antonovsky (1991) defined the concept of sense of coherence as "A global orientation that expresses the extent to which one has a pervasive, enduring though dynamic feeling of confidence that (1) the stimuli deriving from one's internal and external environments in the course of living are structured, predictable and explicable; (2) the resources are available to one to meet the demands posed by these stimuli; and (3) these demands are challenges, worthy of investment and engagement". Various researchers (e.g. Basson \& Rothmann, 2002; Levert et al., 2000; Rothmann \& Jansen van Vuuren, 2002; Wissing, De Waal \& De Beer 1992) reported significant negative correlations between burnout and sense of coherence. It is possible that sense of coherence, as a "meaning-providing variable" (Strümpfer, 2003), may assist in the warding-off of burnout, in recovering from it, as well as probably in strengthening engagement inclinations. Cherniss (1995, p. 185) links burnout to the quest for meaning: "Burnout is a response to stress, but the root cause isn't stress (or suffering). It's the lack of meaning for suffering."

- Generalised self-efficacy. Generalised self-efficacy is described as a general, stable cognition (trait) that individuals have and carry with them and that reflects the expectation that they possess the ability to perform tasks successfully in a variety of achievement situations. According to Wood, Bandura and Bailey (1990) and Judge, Locke and Durham (1997), self-efficacy is an individual's belief or confidence in his or her abilities to deal with specific demands through applying his or her own motivation, cognitive resources and specific actions. People with a strongly developed selfefficacy are therefore less susceptible to stress and consequently to burnout (Eden \& Zuk, 1995). Rothmann and Malan (2002) found a practically significant relationship between generalised self-efficacy and personal accomplishment $(\mathrm{r}>0,50)$, and between generalised selfefficacy and cynicism. Therefore, it seems that low selfefficacy could be related to high levels of burnout.

- Locus of control. Rotter (1966) proposed the concept of locus of control as the perception by the individual of his or her ability to exercise control over the environment. Those characterised by an internal locus of control believe they have control over their environment and their personal successes, whereas those with an external locus of control view their lives as controlled by external factors such as chance or powerful others. There is evidence that an external locus of control is associated with burnout among females working in human services (Brookings, Bolton, Brown \& McEvoy, 1985). Compared with persons with an internal locus of control, those with an external locus of control are more emotionally 
exhausted, depersonalised and experience reduced feelings of personal accomplishment (Schaufeli \& Enzmann, 1998). In a recent review of eleven studies, Glass and McKnight (1996) showed that external locus of control explains about $10 \%$ of the variance of emotional exhaustion and about $5 \%$ of depersonalisation and reduced personal accomplishment.

- Dispositional optimism. Dispositional optimism can be defined as a person's positive outlook towards life events (Carver \& Scheier, 2002). It seems that optimistic people are better equipped to handle stress than pessimistic people. Optimists rely on coping strategies which could help to control or modify aspects of stressors, seek information, and are involved in planning and positive re-framing (Jackson, Weiss \& Lundquist, 2001). Pessimists tend to employ strategies such as negative coping, cognitive or behavioural avoidance, denial, disengagement and/or substance abuse (Harju \& Bolen, 1998). As a result, optimism has mostly been linked to active, persistent, health-oriented coping, while pessimism is more likely to be linked with emotional distress, health concerns and negative coping (Harju \& Bolen, 1998).

- Satisfaction with life. Satisfaction with life is defined as a global evaluation by a person of his or her life (Diener et al., 2002). Satisfaction with life can have implications of how well an individual cope with situations. An individual with a negative future outlook will have difficulties to cope with current stressful work or life situations. In the light of this argument it is reasonable to argue that satisfaction with life could have a moderating effect on stress, burnout and work engagement.

Various other constructs from the paradigm of positive psychology could have moderating/mediating effects on occupational stress, burnout and work engagement. These constructs include resilience (Masten \& Reed, 2002), flow (Nakamura \& Csikszentmihalyi, 2002), positive affectivity (Watson, 2002), coping strategies (Stanton, Parsa \& Austenfeld, 2002) and emotional intelligence (Salovey, Mayer \& Caruso, 2002). However, research is needed to evaluate the effects of these constructs in the work situation as well as the effects of interventions directed at building psychological strengths.

\section{Work wellness interventions}

Research is necessary to determine the effects of interventions on stress, burnout and work engagement in South Africa. Three levels of intervention strategies should be considered (Kompier \& Cooper, 1999):

- Primary level interventions. Primary level interventions are concerned with modifying or eliminating the stressors inherent in the workplace in order to adapt the environment to better fit the individual. The effectiveness and potential cost benefits of primary level interventions have not been rigorously evaluated (Kompier \& Cooper, 1999). The few rigorous studies that were conducted showed significant improvements in employee satisfaction and motivation levels, but productivity outputs improved minimally. Organisational development interventions in general and interventions to influence culture and values should be implemented to contribute to healthier work places. Furthermore, psycho-educational programmes should be developed and presented to combat burnout and to promote work engagement.

Since job demands play a central role in the process that might lead to burnout and health problems, reducing those demands seems to be warranted. Many preventive organisational-based strategies exist to tackle high job demands, such as job redesign, flexible work schedules and goal setting. Increasing job resources (e.g. through participative management, increasing social support and team building), on the other hand, would eventually lead to more engagement at the job, but its direct effect on burnout is small. Hence, from a preventive point of view, decreasing job demands is to be preferred to increasing job resources.
- Secondary level interventions. Secondary level interventions focus on the individual and are concerned with increasing awareness and extending the physical and psychological resources of employees to enable them to minimise the damaging effects of stress and manage stress more effectively. Stress-management programmes that use a cognitivebehavioural approach are effective in reducing stress reactions, including burnout (see Schaufeli \& Enzmann, 1998, pp. 146-168). In common with other forms of training, the effectiveness and potential cost benefits of secondary levels interventions have not been rigorously evaluated. Based on self-report measures, stress management activities would seem to have a modest effect in temporarily reducing experienced stress (Kompier \& Cooper, 1999). However, in isolation, not only do these beneficial effects appear to decay over time, but evidence would seem to indicate that success varies according to the form such activities take and individual receptiveness to the techniques employed. Organisation-based programmes should supplement such individual-based programmes in order to be effective in the long run (Schaufeli \& Bakker, 2002).

- Tertiary level interventions. Tertiary level interventions are targeted at individuals, but their role is recuperative rather than preventative. There is well-documented evidence (Kompier \& Cooper, 1999) to suggest that counselling is effective in improving the psychological well-being of employees and has considerable cost benefits in terms of reduced sickness absence.

Four dimensions of company results should be evaluated when measuring the effects of work wellness interventions, namely financial results, time and personnel resources, customer satisfaction and health and safety (Kompier \& Cooper, 1999). Financial results are taken from an organisation's profit and loss account and balance sheet. Time and personnel resources include hours worked, personnel statistics and personnel reports, which show the levels of staffing and competency that have been used to achieve the financial result. Measurement of customer satisfaction show how effective an organisation has been in satisfying customer's requirements. Health and safety include the physical and psychological working environment, stress, burnout, health, work engagement and job satisfaction.

In summary, the effects of individual and organisational interventions should be researched. Appropriate designs and acceptable sample sizes should be used when conducting research. The practical significance of findings should be computed in addition to statistical significance (Jacobson, Roberts, Berns \& McGlinchey, 1999).

\section{CONCLUSIONS}

There are still many unanswered questions regarding burnout and work engagement in South African organisations. Small and non-representative samples, a lack of relevant statistical analyses and exclusive reliance on cross-sectional survey designs are some of the shortcomings in South African studies. The factorial validity of all measuring instruments of burnout and work engagement as well as factorial invariance thereof for different language and occupational groups in South Africa should be researched (Byrne, 1991). Furthermore, globalisation and the multicultural nature of the South African society demand that research be conducted regarding the equivalence of factors and item bias of burnout and work engagement measures. More research is needed regarding the conceptualisation and measurement of work engagement. Various problems are experienced with the current items of the UWES, such as difficult item wording and positive response sets.

Research is needed regarding the causes, effects and underlying processes of burnout and work engagement for all occupational groups in South Africa. For example, the Job 
Demand - Control Model (Karasek \& Theorell, 1990) could be used to predict that burnout is related to the strain axis and work engagement to the active learning axis (Demerouti, Bakker, Janssen \& Schaufeli, 2001a). Also, the Job-Demand Resources Model could be used to test to which extent job demands are related to the affective dimension of well-being (burnout) and job resources to the cognitive dimension (Demerouti et al., 2001b). Target groups for intervention research should be identified from these studies.

Until recently little research has been done regarding positive aspects of human behaviour in the work context, while much attention has been paid to unhealthy and dysfunctional aspects. It is clear that the focus should change towards the strengths of human beings in the work context. Consequently, well-being should not just be regarded as the absence of illness or dysfunctional behaviour. Research regarding the dynamics underlying psychological strengths which could create tendencies contrary to those that produce burnout or favourable to work engagement should be conducted. Measuring instruments of psychological strengths on cognitive, affective and behavioural levels should be developed and validated. Because of the problems associated with measurement in multicultural contexts analyses should not only focus on internal consistency, test-retest reliability and construct validity, but also on bias and equivalence.

In studying work engagement, researchers should consider using positively phrased rather than negatively phrased items to measure job resources. Furthermore, research is needed to determine whether psychological strengths and work engagement contribute to a reduction in sick leaves, and increase in productivity, job satisfaction and quality of goods and services.

\section{REFERENCES}

Antonovsky, A. (1979). Health, stress and coping: New perspectives on mental and physical well-being. San Francisco: Jossey-Bass.

Antonovsky, A. (1987). Unravelling the mystery of health: How people manage stress and stay well. San Francisco: Jossey-Bass.

Antonovsky, A. (1991). The structural sources of salutogenic strengths. In C.L. Cooper \& R. Payne (Eds.), Personality and stress: Individual differences in the stress process. New York: Wiley.

Arbuckle J.L. (1997). Amos users' guide version 4.0. Chicago, IL: Smallwaters Corporation.

Bakker, A., Schaufeli, W.B. \& Van Dierendonck, D. (2000). Burnout: Prevalentie, risicogroepen en risicofactoren. In: I.L.D.Houtman, W.B. Schaufeli \& T. Taris (Red.), Psychische vermoeidheid en werk: Cijfers, trends en analyses (pp. 65-82). Alphen a/d Rijn: Samsom.

Bandura, A. (1977). Self-efficacy: Toward a unifying theory of behaviour change. Psychological Review, 84, 191-215.

Barling, J. (1999). Changing employment relations: Empirical data, social perspectives and policy options. In D.B. Knight \& A. Joseph (Eds.), Restructuring societies: Insights from the social sciences (pp. 59-82). Ottawa: Carlton University Press.

Basson, M.J. \& Rothmann, S. (2002). Sense of coherence, coping and burnout of pharmacists. South African Journal of Economic and Management Sciences, 5 (1), 35-62.

Boles, J.S., Dean, D.H., Ricks, J.M., Short, J.C. \& Wang, G. (2000). The dimensionality of the Maslach Burnout Inventory across small business owners and educators. Journal of Vocational Behavior, 56 (1), 12-34.

Bouman, A.M., Te Brake, H. \& Hoogstraaten, J. (2002). Significant effects due to rephrasing the Maslach Burnout Inventory's Personal Accomplishment items. Psychological Reports, 91, 825-826.

Brookings, J.B., Bolton, B., Brown, C.E. \& McEvoy, A. (1985). Selfreported job burnout among female human service professionals. Journal of Occupational Behaviour, 6, 143-150.
Byrne, B.M. (1991). The Maslach Burnout Inventory: Validating factorial structure and invariance across intermediate, secondary and university educators. Multivariate Behavioral Research, 26, 583-605.

Carver, C.S. \& Scheier, M.F. (2002). Optimism. In C.R. Snyder \& S.J. Lopez (Eds.). Handbook of positive psychology. (pp. 231243). Oxford: Oxford University Press.

Cherniss, C. (1995). Beyond burnout: Helping teachers, nurses, therapists and lawyers recover from stress and disillusionment. New York: Routledge.

Chiu, R.K., Man, J.S.W. \& Thayer, J. (1998). Effects of role conflicts and role satisfactions on stress of three professions in Hong Kong: A path analysis approach. Journal of Managerial Psychology, 13, 318-333.

Cooper, C.L., Dewe, P.J. \& O’Driscoll, M.P. (2001). Organizational stress: A review and critique of theory, research and applications. Thousand Oaks, CA: Sage.

Demerouti, E., Bakker, A.B., Janssen, P.P.M. \& Schaufeli, W.B. (2001a). Burnout and engagement at work as a function of demands and control. Scandinavian Journal of Work and Environment and Health, 27, 279-186.

Demerouti E., Bakker, A.B., Nachreiner, F., \& Schaufeli, W.B. (2001b). The job demands - resources model of burnout. Journal of Applied Psychology, 86, 499-512.

Demerouti, E., Bakker, A.B., Vardakou, I. \& Kantas, A. (2003). The convergent validity of two burnout instruments: A multitrait-multimethod analysis. European Journal of Psychological Assessment, 19 (1), 12-23.

Diener, E., Lucas, R.E. \& Oishi, S. (2002). Subjective well-being: The science of happiness and life satisfaction. In C.R. Snyder $\&$ S.J. Lopez (Eds.). Handbook of positive psychology. (pp. 6373). Oxford: Oxford University Press.

Diener, E., Suh, E.M., Lucas, R.E. \& Smith, H.I. (1999). Subjective wellbeing: Three decades of progress. Psychological Bulletin, $125,267-302$

Dubrin, A.J. (1990). Effective business psychology (3 ${ }^{\text {rd }}$ ed.). Englewood Cliffs, NJ: Prentice- Hall.

Eden, D. \& Zuk, Y. (1995). Seasickness as a self-fulfilling prophecy: Raising self-efficacy to boost performance at sea. Journal of Applied Psychology, 80, 628-635.

Frankl, V.E. (1967). Psychotherapy and existentialism. New York: Washington Square Press.

Frese, M., Fay, D., Hilburger, T., Leng, K. \& Tag, A. (1997). The concept of personal initiative: Operationalization, reliability and validity in two German samples. Journal of Occupational and Organizational Psychology, 70, 139-161.

Freudenberger, H.J. (1974). Staff burnout. Journal of Social Issues, 30, 159-165.

Glass, D.C. \& McKnight, J.D. (1996). Perceived control, depressive symptomatology, and professional burnout: A review of the evidence. Psychology and Health, 11, 23-48.

Gorter, R.C., Albrecht, G., Hoogstraten, J. \& Eijkman, M.A.J. (1999, March). Factorial validity of the Maslach burnout inventory - Dutch version (MBI-NL) among dentists. Journal of Organizational Behavior, 20, 209-217.

Harju, B. \& Bolen, L.M. (1998). The effects of optimism on coping and perceived quality of life of college students. Journal of Social Behavior and Personality, 13, 185-200.

Hart, P.M. (1999). Predicting employee life satisfaction: A coherent model of personality, work and non-work experiences, and domain satisfaction. Journal of Applied Psychology, 84, 564-584.

Jacobson, N.S., Roberts, L.J., Berns, S.B. \& McGlinchey, J.B. (1999). Journal of Consulting and Clinical Psychology, 3, 300307.

Jackson, T. Weiss, K. \& Lundquist, J.J. (2001). Does procrastination mediate the relationship between optimism and subsequent stress? Journal of Social Behavior \& Personality, 16, 203-213.

Judge, T.A., Locke, E.A. \& Durham, C.C. (1997). The dispositional causes of job satisfaction: A core evaluations approach. Research in Organisational Behaviour, 19, 151-188. 
Judge, T.A. \& Watanabe, S. (1993). Another look at the job satisfaction-life satisfaction relationship. Journal of Applied Psychology, 78, 939-948.

Kalliath, T.J., O'Driscoll, Gillespie \& Bluedorn, A.C. (2000). A test of the Maslach Burnout Inventory in three samples of healthcare professionals. Work and Stress, 14, 35-51.

Karasek, R.A., \& Theorell, T. (1990). Healthy work: Stress, productivity and the reconstruction of working life. New York: Basic Books.

Kelloway, E.K. \& Barling, J. (1991). Job characteristics, role stress and mental health. Journal of Occupational Psychology, 64, 291-304.

Keyes, C.L.M. \& Haidt, J. (2003). Introduction: Human Flourishing - the study of what makes life worthwhile. In C.L.M. Keyes \& J. Haidt (Eds.), Flourishing: Positive psychology and the life well-lived. Washington, DC: American Psychological Association.

Kirchler, E. (1985). Job loss and mood. Journal of Economic Psychology, 6 (1), 9-25.

Kompier, M. \& Cooper, C. (1999). Preventing stress, improving productivity. London: Routledge.

Kruger, M.M., Veldman, H., Rothmann, S. \& Jackson, L.T.B. (2002, July). Burnout, job satisfaction, sense of coherence and job stress in a local government. Paper presented at the $25^{\text {th }}$ International Conference of Applied Psychology, Singapore.

Leiter, M.P. \& Schaufeli, W.B. (1996). Consistency of the burnout construct across occupations. Anxiety, Stress, and Coping, 9, 229-243.

Levert, T., Lucas, M. \& Ortlepp, K. (2000). Burnout in psychiatric nurses: Contributions of the work environment and a Sense of Coherence. South African Journal of Psychology, 30, 36-43.

Levert, T., Lucas, M. \& Ortlepp, K. (2000). Burnout in psychiatric nurses: Contributions of the work environment and a sense of coherence. South African Journal of Psychology, 30, 36-43.

Luthans, F. (2002a). Positive organizational behaviour: Developing and maintaining psychological strengths. Academy of Management Executive, 16, 57-72.

Luthans, F. (2002b). The need for and meaning of positive organizational behaviour. Journal of Organizational Behaviour, 23, 695-706.

Martin, P. (1997). The sickening mind: Brain, behaviour, immunity and disease. London: HarperCollins.

Maslach, C. (1998). A multidimensional view of burnout. In C.L. Cooper (Ed.) Theories of organizational stress. (pp. 68-85). Oxford: Oxford University Press.

Maslach, C. \& Jackson, S.E. (1986). Maslach Burnout Inventory: Manual (2nd ed.). Palo Alto, CA: Consulting Psychologists Press.

Maslach, C. \& Leiter, M.P. (1997). The truth about burnout. San Francisco: Jossey-Bass.

Maslach, C. \& Schaufeli, W.B. (1993). Historical and conceptual development of burnout. In W.B. Schaufeli, C. Maslach \& T. Marek (Eds.), Professional burnout: Recent developments in theory and research (pp. 1-16). Washington, DC: Taylor $\&$ Francis.

Maslach, C., Jackson, S.E. \& Leiter, M. (1996). Maslach Burnout Inventory: Manual (3 $3^{\text {rd }}$ ed.). Palo Alto, CA: Consulting Psychologists Press.

Maslach, C., Jackson, S.E. \& Leiter, M.P. (1997). Maslach Burnout Inventory: Third edition. In C.P. Zalaquett \& R.J. Wood (Eds.), Evaluating stress: A book of resources (pp. 191-218). Lanham, MD: Scarecrow Press Inc.

Maslach, C. \& Leiter, M.P. (1997). The truth about burnout. San Francisco: Jossey-Bass.

Maslach, C., Schaufeli, W.B. \& Leiter, M.P. (2001). Job burnout. Annual Review of Psychology, 52, 397-422.

Masten, A.S. \& Reed, M.G.J. (2002). Resilience in development. In C.R. Snyder \& S.J. Lopez (Eds.). Handbook of positive psychology. (pp. 74-88). Oxford: Oxford University Press.

Myers, D.G. (2000). The funds, friends, and faith of happy people. American Psychologist, 55, 56-67.
Nakamura, J. \& Csikszentmihalyi, M. (2002). The concept of flow. In C.R. Snyder \& S.J. Lopez (Eds.). Handbook of positive psychology. (pp. 89-105). Oxford: Oxford University Press.

Naudé, J.L.P. (2003). Occupational stress, coping, burnout and work engagement of emergency workers in Gauteng. Unpublished doctoral thesis, PU for CHE, Potchefstroom.

Naudé, J.L.P. \& Rothmann, S. (in press). The validation of the Maslach Burnout Inventory - Human Services Survey for emergency workers in Gauteng. Manuscript submitted for publication.

Nunnally, J.C. \& Bernstein, I.H. (1994). Psychometric theory (3 ${ }^{\text {rd }}$ ed.). New York: McGraw-Hill.

Pienaar, J. (2002). Coping, stress and suicide ideation in the South African Police Service. Unpublished doctoral thesis, Potchefstroom University for CHE, Potchefstroom.

Pines, A. (1993). Burnout: An existential perspective. In W.B Schaufeli, C. Maslach \& T. Marek (Eds.). Professional burnout: Recent developments in theory and research (pp. 3351).Washington: Taylor \& Francis.

Pretorius, T.B. (1994). Using the Maslach Burnout Inventory to assess educators' burnout at a university in South Africa. Psychological Reports, 75, 771-777.

Roberts, D.R. \& Davenport, T.O. (2002). Job engagement: Why it's important and how to improve it. Employment Relations Today, 29 (3), 21-29.

Ross, E. \& Fridjhon, P. (1995). Burnout: A smoldering problem among South African social workers. Social Work, 31, 265-279.

Rothmann, S. (2001). Sense of coherence, locus of control, selfefficacy and job satisfaction. Journal of Economic and Management Sciences, 5 (1), 41-65.

Rothmann, S. (2002, March). Burnout research in South Africa. Paper presented at the $1^{\text {st }}$ South African Conference on Burnout, Potchefstroom.

Rothmann, S. \& Malan, H. (2002, March). Koherensiesin, selfdoeltreffendheid, lokus van beheer en uitbranding by maatskaplike werkers. Poster session presented at the 1st South African Burnout Conference, Potchefstroom.

Rothmann, S. \& Jansen van Vuuren, J.A. (2002, March). Sense of coherence, self-efficacy, locus of control, coping and burnout of senior managers in a manufacturing industry. Poster session presented at the $1^{\text {st }}$ South African Burnout Conference, Potchefstroom.

Rothmann, S. \& Storm, K. (2003, May). Engagement in the South African Police Services. Poster session presented at the $11^{\text {th }}$ European Congress on Work and Organizational Psychology. Lisbon, Portugal.

Rothmann, S. \& Van Rensburg, P. (2002). Psychological strengths, coping and suicide ideation in the South African Police Services in the North West Province. South African Journal of Industrial Psychology, 28 (3), 39-49.

Rotter, J.B. (1966). Generalised expectancies for internal versus external control of reinforcement. Psychological Monographs, $80,1-28$.

Russell, J.A. \& Carroll, J.M. (1999). On the bipolarity of positive and negative affect. Psychological Bulletin, 125, 3-30.

Ryan, R.M. \& Deci, E.L. (2000). Self-determination theory and the facilitation of intrinsic motivation, social development, and well-being. American Psychologist, 55, 68-78.

Salovey, P., Mayer, J.D. \& Caruso, D. (2002). The positive psychology of emotional intelligence. In C.R. Snyder \& S.J. Lopez (Eds.). Handbook of positive psychology. (pp. 159-171). Oxford: Oxford University Press.

Schabracq, M.J., Winnubst, J.A.M. \& Cooper C.L. (1996) Handbook of work and health psychology. Chichester: Wiley.

Schaufeli, W.B. \& Bakker, A.B. (2001). Werk en welbevinden: Naar een positieve benadering in de Arbeids- en Gezondheidspsychologie [Work and wellbeing: Towards a positive occupational health psychology]. Gedrag en Organizatie, 14, 229-253.

Schaufeli, W.B. \& Bakker, A.B. (2002). Job demands, job resources and their relationship with burnout and engagement: A multisample study on the COBE-model. Utrecht University: Psychology and Health. 
Schaufeli, W.B., Bakker, A.B., Hoogduin, K., Schaap, C. \& Kladler, A. (2001). On the clinical validity of the Maslach Burnout Inventory and the burnout measure. Psychology and Health, $16,565-583$.

Schaufeli, W.B. \& Enzmann, D. (1998). The burnout companion to study and practice: A critical analysis. London: Taylor \& Francis.

Schaufeli, W.B., Leiter, M.P. \& Kalimo, R. (1995, September). The General Burnout Questionnaire: Gross-national development and validation. Paper presented at the APA/NIOSH Congress Work, Stress and Health, Creating Healthier Workplaces, Washington, DC.

Schaufeli, W.B., Martinez, I., Pinto, A.M., Salanova, M. \& Bakker, A.B. (2002). Burnout and engagement in university students: A cross-national study. Journal of Cross-Cultural Psychology, 33, 464-481.

Schaufeli, W.B., Salanova, M., González-Romá, V. \& Bakker, A.B. (2002). The measurement of engagement and burnout: A confirmative analytic approach. Journal of Happiness Studies, 3, 71-92.

Schaufeli, W.B. \& Van Dierendonck, D. (1995). A cautionary note about the cross-national and clinical validity of cut-off points for the Maslach Burnout Inventory. Psychological Reports, 76, 1083-1090.

Schutte, N., Toppinen, S., Kalimo, R. \& Schaufeli, W.B. (2000, March). The factorial validity of the Maslach Burnout Inventory - General Survey (MBI-GS) across occupational groups and nations. Journal of Occupational and Organizational Psychology, 73 (1), 53-66.

Seligman, M.E.P. \& Csikszentmihalyi, M. (2000). Positive psychology: An introduction. American Psychologist, 55, 5-14.

Snyder, C.R. \& Lopez, S.J. (2002). Handbook of positive psychology. Oxford: Oxford University Press.

Stanton, A.L., Parsa, A. \& Austenfeld, J.A. (2002). The adaptive potential of coping through emotional approach. In C.R. Snyder \& S.J. Lopez (Eds.). Handbook of positive psychology. (pp. 148-158). Oxford: Oxford University Press.

Storm, K. (2002). Burnout and work engagement in the South African Police Service. Unpublished doctoral thesis, Potchefstroom University for CHE, Potchefstroom.

Storm, K. \& Rothmann, S. (2002, March). The relationship between burnout, personality traits and coping strategies in a corporate pharmacy group. Paper presented at the 1st South African Burnout Conference, Potchefstroom.

Storm, K. \& Rothmann, S. (2003a, May). Burnout in the South African Police Service. Poster session presented at the 11th European Congress on Work and Organizational Psychology, Lisbon, Portugal.

Storm, K. \& Rothmann, S. (2003b, June). A psychometric analysis of the Maslach Bunrut Inventory in the South African Police Service. Paper presented at the $6^{\text {th }}$ Annual Conference of the Society of Industrial and Organisation Psychology of South Africa, Johannesburg.
Strümpfer, D.J.W. (1990). Salutogenesis: A new paradigm. South African Journal of Psychology, 20, 265-276.

Strümpfer, D.J.W. (1995). The origins of health and strength: from 'salutogenesis' to 'fortigenesis'. South African Journal of Psychology, 25, 81-89.

Strümpfer, D.J.W. (2002, March). Resiling: A stitch that saves nine. Paper presented at the $1^{\text {st }}$ South African Burnout Conference, Potchefstroom.

Taris, T.W., Schreurs, P.J.G. \& Schaufeli, W.B. (1999). Construct validity of the Maslach Burnout Inventory - General Survey: A two-sample examination of its factor structure and correlates. Work and Stress, 13, 223-237.

Turner, N., Barling, J. \& Zacharatos, A. (2002). Positive psychology at work. In C.R. Snyder \& S.J. Lopez (Eds.), Handbook of positive psychology. (pp. 715-728). Oxford: Oxford University Press.

Van de Vijver, F. \& Leung, K. (1997). Methods and data-analysis for cross-cultural research. Thousand Oaks, CA: SAGE.

Van de Vijver, F. \& Tanzer, N.K. (1997). Bias and equivalence in cross-cultural assessment: An overview. European Review of Applied Psychology, 47, 263-279.

Van der Linde, A.H., Van der Westhuizen, P.C. \& Wissing, M.P. (1999). Burnout in female educators. South African Journal of Education, 19 (3), 192-196.

Warr, P. (1983). Work, jobs and unemployment. Bulletin of the British Psychological Society, 36, 305-311.

Watson, D. (2002). Positive affectivity: The disposition to experience pleasurable emotional states. In C.R. Snyder \& S.J. Lopez (Eds.). Handbook of positive psychology. (pp. 106-119). Oxford: Oxford University Press.

Watson, D. \& Tellegen, A. (1985). Toward a consensual structure of mood. Psychological Bulletin, 98, 219-235.

Wissing, M.P., de Waal, M. \& de Beer, I. (1992, July). Sense of coherence and stress symptomatology. Paper presented at $25^{\text {th }}$ International Congress of Psychology, Brussels, Belgium.

Wissing, M.P. \& van Eeden, C. (1997, September). Psychological well-being: A fortigenic conceptualization and empirical clarification. Paper presented at Annual Congress of the Psychological Society of South Africa, Durban, South Africa.

Wood, R.E., Bandura, A. \& Bailey, T. (1990). Mechanisms governing organizational performances in complex decision making environments. Organizational Behavior and Human Decision Processes, 46, 181-201.

Wright, T.A. (2003). Positive organizational behaviour: An idea whose time has truly come. Journal of Organizational Behavior, 24, 437-442.

Wright, T.A. \& Cropanzano, R. (2000). The role of organizational behaviour in occupational health psychology: A view as we approach the millennium. Journal of Occupational Health Psychology, 5, 5-10. 